\title{
Makna Reformasi Hukum Bagi Pelaku Bisnis di Indonesia
}

\author{
Mudjiono
}

\begin{abstract}
Reformation in law brings a significant influence for businessman in Indonesia. The alteration of a legal direction will bring a policy alteration of business. In view of that, it is need to base the alteration on a good management strategy to prevent a monetary fluctuation as occurred in the past that caused by uncompatible government legal policy.
\end{abstract}

\section{Pendahuluan}

Ada banyak fakta dan permasalahan yang bersangkutan dengan hukum dan dunia penegakan hukum di Indonesia, yang menunjukkan bahwa produk hukum nasional Indonesia tidak berbobot, lamban, tidak profesional dan sarat dengan personal-personal yang bermental bobrok dan korup. Sebagai contoh, dalam 2002 hingga 2003, banyak sekali putusan hakim yang menjadi sorotan masyarakat karena dinilai kontroversial, misalnya kasus pailit Manulife yang penuh dengan skandal suap, putusan hakim atas kasus pelanggaran hak asasi manusia (HAM) di Timor Timur yang pelakunya dibebaskan, kasus Letter of Credit fiktif yang menjebol keuangan BNI 46 dan sebagainya.

Ibarat rumah yang direnovasi, itulah yang tengah dilakukan Indonesia. Tumbangnya rejim Orde Lama yang ditandai dengan mundurnya Presiden Soeharto dari tampuk kepemimpinan tertinggi nasional merupakan awal dari era reformasi. Dalam era baru ini, keseluruhan sistem politik dan sistem hukum ditata ulang dengan tujuan agar wajah hukum nasional yang masih pluralistik, kegagalan sistem peradilan di masa lampau, intervensi' publik terhadap hukum, masalah pengadilan niaga, masalah kekerasan dalam masyarakat, tidak terulang lagi di masa mendatang. Inilah yang kemudian dikenal dengan istilah reformasi hukum. Pertanyaannya, apakah makna reformasi hukum tersebut bagi pelaku bisnis di Indonesia?

\section{Paradigma Reformasi}

Kerangka utama strategi politik yang berkenaan dengan pembinaan dan pengembangan hukum nasional dalam tiga dasawarsa belakangan ini pada prinsipnya 
mempunyai konsep dasar yang sama, yaitu dengan berpedoman pada UUD 1945. Yang menjadi landasan ideal bagi pembinaan dan pengembangan hukum nasional adalah Pancasila, sedangkan yang dijadikan landasan politis dan operasionalnya adalah tujuan nasional yang tertuang dalam Pembukaan UUD 1945. Untuk menjalankan pembangunan, sistem pemerintahan presidensiil dijadikan landasan struktur kelembagaan pemerintahannya, dimana semua kebijakan pemerintahan yang diselenggarakan pada dasarnya mengacu kepada public policy yang diatur dalam GBHN.

Apabila dikaitkan dengan paradigma pembinaan dan pengembangan hukum nasional sebagaimana diuraikan di atas, lengsernya Soeharto disebabkan karena selaku top administrator dan top management, Soeharto tidak konsisten menjabarkan pesanpesan politik yang térkandung di dalam GBHN. Selain. itu, Soeharto telah melakukan manipulasi kebijakan melalui penerbitan berbagai keputusan Presiden yang tidak sesuai dengan paradigma keadilan sosial yang diamanatkan Pancasila, UUD 1945 dan GBHN.

Makna keadilan sosial yang kini marak dikumandangkan oleh masyarakat Indonesia berbeda konsepnya dengan makna keadilan sosial bagi masyarakat negara lain. Di Indonesia, makna keadilan sosial adalah keadilan sosial yang berkerakyatan. Dalam konteks pengertian tersebut, adil, tidak hanya meliputi bidang ekonomi saja, namun harus juga mampu merasuki bidang-bidang kehidupan lainnya seperti bidang sosial, politik, budaya dan hankamtibmas.

Dalam upaya mencapai keadilan sosial tersebut, aspek-aspek politik, ekonomi dan hukum saling berkaitan. Selain dapat menunjang keberhasilan dalam mewujudkan keadilan sosial, ketiga aspek tersebut di atas dapat pula menjadi pangkal utama pelecehan paradigma keadilan sosial yang berujung pada timbulnya friksi-friksi dan konflik sosial budaya serta kamtibmas. Korupsi, kolusi dan nepotisme (KKN) merupakan panggung utama bagi terjadinya praktik-praktik yang membidangi ketiga aspek tersebut, yang dikuasai oleh para elit politik, elit ekonomi dan elit intelektual. Selain terjadi kolusi antar sesama elit penguasa, kolusi juga dapat terjadi di antara penguasa dengan para pengusaha, yang akhimya menimbulkan kerawanan bagi upaya penegakan hukum dan keadilan.'

KKN menyebabkan pengeroposan mental dan perilaku para elit dalam jaringan kerja antar penguasa, antara penguasa dengan pengusaha dan bahkan pada sebagian masyarakat. Apabila kondisi ini dibiarkan berkelanjutan, fondasi dan pilar-pilar pemerintahan yang seharusnya tegak dan berwibawa akan rapuh dan hancur.

Dewasa ini, bidang sosial ekonomi tampak lebih menonjol dan menuntut perhatian ekstra dibandingkan dengan bidang-bidang kehidupan lainnya. Hal ini disebabkan karena dalam praktiknya, kesalahan dan/atau kelalaian sekecil apapun yang terjadi dalam bidang ekonomi akan menimbulkan goncangan politik di dalam maupun di luar negeri. Ketidakstabilan ekonomi dapat menimbulkan instabilitas di

\footnotetext{
${ }^{1}$ Solly Lubis, Politik dan Hukum di Era Reformasi (Bandung, Mandar Maju, 2000), hlm. 41.
} 
bidang keamanan dan ketertiban, yang akhirnya dapat menyebabkan benturanbenturan sosial budaya. Demikian dahsyatnya goncangan tersebut, sehingga dapat mengancam keutuhan, persatuan dan kesatuan berbangsa dan bernegara. Sebagai contoh dapat dilihat pada akibat penerapan kebijakan moneter oleh Pemerintah yang menyebabkan banyak bank dilikuidasi. Salah satu dampak yang sangat dirasakan pada saat itu adalah penurunan nilai mata uang rupiah di pasaran internasional dan penarikan simpanan masyarakat secara besar-besaran (rush), misalnya yang terjadi pada BCA di era 1990-an.

Kelemahan hukum yang kemudian dimanfaatkan oleh sejumlah oknum untuk mengeruk keuntungan ekonomi sebesarbesarnya membuat hukum cacad di mata masyarakat. Bagi sejumlah pihak, hukum malah diciptakan untuk melegitimasi tindakan yang dilakukannya. Akibatnya, masyarakat bingung, resah dan tidak ada kepastian hukum. Hal ini tentu saja berdampak buruk pada sektor usaha. Banyak pengusaha lokal maupun internasional yang tertarik untuk membuka hubungan dagang dengan Indonesia batal atau memutuskan hubungan dagang yang telah dibinanya karena hukum di Indonesia dipandang tidak mampu melindungi kepentingan bisnis mereka.

\section{Reformasi Hukum dan Hukum Reformatif}

Disaat krisis kepercayaan dan pencarian akan suatu format konstitusionalisme yang dapat disepakati oleh semua kekuatan politik dan diterima oleh segenap masyarakat, kondisi interdependen antara politik dan hukum memerlukan penanganän dengan bijak dan segera. Hal ini dimaksudkan agar masyarakat tidak berlarut-larut berada dalam ketegangan sosial yang sedang berlangsung. Apabila hal ini tidak ditindaklanjuti, maka ketidakpercayaan masyarakat terhadap kemampuan dan wibawa Pemerintah sebagai penguasa akan terus berlangsung, bahkan akan mengembangkan friksi serta kecurigaan antar sesama kelompok masyarakat politik.

Pada saat ini, jelaslah bahwa paradigma kerakyatan dan keadilan sosial mencuat ke permukaan. Oleh karena itu, paradigma ini pula yang seharusnya digunakan untuk menata kembali sistem hukum Indonesia, terutama yang berkaitan dengan tatanan kehidupan berpolitik, baik mengenai keorganisasian, pemilihan umum dan penataan lembaga-lembaga perwakilan rakyat, termasuk perimbangan kekuasaan dan keuangan antara Pemerintah Pusat dan Pemerintah Daerah.

Banyak pihak telah melakukan analisis. terhadap sistem hukum dan pembaharuannya dengan mengacu kepada Pancasila dan UUD 1945. Secara antisipatif juga telah dibahas mengenai pembangunan hukum sampai pada tahapan-tahapan Pelita. Kesemuanya itu ditujukan untuk mencapai lalu lintas hukum yang lebih baik, menyangkut kehidupan nonpolitis khususnya hukum ekonomi (economic law), hukum bisnis (business law), hukum perdata (civil law), hukum pidana maupun hukum formil (hukum acara).

Pengalaman di masa lampau yang hingga kini masih dirasakan dampaknya adalah peraturan hukum berupa produk pimpinan eksekutif (Presiden) dalam bentuk Keputusan Presiden (Keppres) masih banyak berlaku. Dipandang dari sudut kepentingannya, 
kepentingan ekonomis yang melekat pada sejumlah Keppres tersebut masih sangat dominan, dimana proteksi hukum bagi golongan masyarakat yang mempunyai tingkat ekonomi lemah masih sangat kurang, sementara peluang usaha bagi perusahaanperusahaan besar terbuka lebar dan prosedurnya sangat mulus.

Banyaknya perusahaan kecil terpinggirkan, bahkan tidak jarang terpaksa gulung tikar. Sejumlah lahan pertanian yang tadinya dikuasai rakyat kecil beralih fungsi dan kepemilikan menjadi pabrik-pabrik dan industri milik pengusaha-pengusaha besar. Sedangkan kondisi hidup di perkotan tidak selalu cerah dan menjanjikan bagi para petani dan buruh tani yang terdesak dari perdesaan sehingga menjadi urban. Semua hal tersebut diatas merupakan dampak dari kebijakan regulasi yang kendali utamanya terletak di tangan Presiden selaku chief executive dan disebabkan oleh kurang aktifnya atau lembaga-lembaga negara untuk melakukan kontrol terhadap kebijakan Presiden.

Banyak Keppres yang seharusnya diuji kembali, baik dari segi kewenangannya (uji formil) maupun dari segi substansinya (uji materiil). Pasal 26 Undang-undang Nomor 14 Tahun 1970 tentang Pokok-pokok Kekuasaan Kehakiman yang memberikan wewenang uji materiil kepada Mahkamah Agung perlu diterapkan sungguh-sungguh.

\section{Reformasi di Bidang Peradilan}

Kegagalan peradilan yang berarti gagal memberi keadilan kepada masyarakat, gagal menerapkan hukum sebagaimana mestinya, gagal memproses para pelaku pelangar hukum secara tepat dan seterusnya, membuat . pengadilan menjadi sesat. Kegagalan peradilan itu sendiri dapat disebabkan oleh ketidakmampuan (unability) atau ketidakmauan (unwillingness). Kegagalan peradilan disebabkan oleh ketidakmampuan jika dari proses awal sebuah perkara hingga proses akhirnya terbukti bahwa aparat kepolisian dan kejaksaan tidak mampu melakukan penyelidikan dan penyidikan dengan baik. $\mathrm{Hal}$ ini tampak dari rendahnya kualitas sumber daya manusia penegak hukum dan banyaknya perkara pidana yang diperdatakan atau sebaliknya, banyak perkara perdata yang dipidanakan, di mana hal itu terlihat sangat dipaksakan.

Dalam proses penyidikan, kerap dijumpai BAP yang sengaja dibuat standar sehingga mudah ditandatangani tersangka. Hal ini jelas akan merugikan masyarakat, terutama pihakpihak yang buta huruf. Pengacara dan hakim yang seharusnya menjadi penegak hukum kadangkala justru menjadi biang dari perilaku koruptif. Kondisi hukum yang bobrok inilah yang ingin direformasi oleh rejim pasca Soeharto.

Hukum, ekonomi dan politik adalah faktorfaktor resiprokal yang saling mempengaruhi. Hal ini dapat dilihat pada banyak kejadian dalam 3 (tiga) tahun terakhir ini, dimana hukum dan penegakan hukum sangat dipengaruhi oleh kondisi politik, ekonomi dan kekuasaan. Sebagai contoh, dalam masa kepemimpinan Habibie, banyak peraturan yang dikeluarkan guna memulihkan keadaan ekonomi dan memberantas KKN yang merajalela di Indonesia. Namun yang terjadi dalam praktik, sejumlah peraturan yang dikeluarkan tersebut saling bertentangan sehingga membingungkan masyarakat dan akhirnya menciptakan ketidakpastian hukum. 
Sementaraitu, dalam kondisi transplacement itu pula penduduk Indonesia dihadapkan pada berbagai peristiwa kerusuhan, pertentangan antar suku, pengeroyokan, perusakan serta pembakaran institusi kenegaraan/pemerintahan, bahkan perlawanan terbuka terhadap otoritas dan kekuasaan yang sah sebagaimana terjadi di Propinsi Nangroe Aceh Darussalam. Akibat yang langsung terasa saat itu adalah instabilitas di bidang pertahanan keamanan dan melemahnya nilai tukar rupiah terhadap mata uang asing. Travell warning pun dilakukan oleh berbagai negara untuk mencegah warganya datang ke Indonesia sehingga pendapatan lewat devisa Indonesia menjadi turun.

Dalam kondisi yang transplacement, sulit disangkal adanya kesenjangan antara hukum dan praktik. Conflict yang terjadi antara teori hukum dan praktik hukum telah menimbulkan kesan seolah-olah hukum dan praktik tidak akan pernah sejalan. Hukum dipandang selalu ketinggalan dan tidak up to date. Terhadap kondisi sedemikian, tindakan yang dilakukan para sarjana hukum, baik pengacara, polisi jaksa maupun hakim cenderung bersifat justifikasi terhadàp keberadaan hukum, bahkan tidak jarang yang berperan melindungi kebobrokan hukum itu sendiri. Inilah yang menyebabkan suatu bangsa sulit keluar dari kesenjangan tersebut, bahkan sebaliknya, menjadi semakin gila. ${ }^{2}$

Untuk mengatasi keterpurukan hukum, Pemerintah segera melakukan reformasi dibidang peradilan. Bagi upaya penyelesaian sengketa niaga contohnya, Pemerintah membentuk Pengadilan Niaga di 5 (lima) kota besar di Indonesia untuk secara khusus menangani masalah-masalah yang berkaitan dengan bisnis/niaga. Keberadaan Pengadilan Niaga ini ternyata tidak membawa hasil yang significant dalam upaya pembaharuan hukum peradilan. Lokasi pengadilan yang jauh dari tempat terjadinya sengketa niaga tidak diimbangi dengan pembukaan kantor-kantor cabang yang dapat membantu pendaftaran maupun pengurusan administrasi sengketa niaga. Hal ini menjadi salah satu faktor penyebab lembaga peradilan niaga tidak berfungsi secara optimal. Ini tampak dari banyaknya kasus niaga yang tetap diajukan ke Pengadilan Negeri.

\section{Reformasi Hukum sebagai Fasilitas Pemulihan Ekonomi Nasional}

Hukum tidak akan terlepas dari ekonomi. Banyak sekali kepentingan ekonomi yang terlibat dalam pembuatan dan penegakan hukum di Indonesia. Reformasi hukum dibidang ekonomi yang saat ini dilakukan adalah untuk membuat agar hukum dapat menjadi fasilitator bagi pemulihan dan pendorong kegiatan ekonomi nasional. Perwujudan reformasi hukum, terutama dalam tindakan pemberantasan korupsi dan memperkuat penegakan hukum dinilai akan dapat mendorong upaya pemulihan ekonomi nasional yang sedang terpuruk. Pendapat senada juga diutarakan oleh Menteri Luar Negeri Amerika Serikat Colin Powel dalam jumpa persnya bersama Menteri Perekonomian

${ }^{2}$ L. Michael Hager, Peranan Hukum di Masa Transisi Demokrasi Negara Berkembang (Jakarta: Center of Law and Justice Studies, Jurnal Keadilan Vol. 1 No. 2), Juni 2002. 
Dorodjatun Kuntjorojakti di Jakarta pada tanggal 8 Pebuari 2002. Bersihnya perekonomian dari unsur-unsur KKN, akan mendorong masuknya investasi asing yang diperlukan bagi pembangunan yang berkelanjutan.

Untuk meminimalisasi kemungkinan terjadinya KKN, dibentuklah undang-undang anti korupsi, kolusi dan nepotisme. Dalam undang-undang tersebut, secara tegas dinyatakan bahwa setiap pelaku tindakan KKN diancam dengan sanksi hukum.

Di awal tahun pemerintahan Presiden Megawati Soekarno Putri, reformasi hukum mulai menunjukkan hasilnya. Hal ini tampak pada perbaikan ekonomi nasional, namun kemudian di akhir tahun 2002 laju pertumbuhan ekonomi nasional mulai.stagnan dan bahkan menurun. ${ }^{3}$ Salah satu faktor pemicu merosotnya laju pertumbuhan perekonomian nasional adalah keinginan Pemerintah untuk menjual aset-aset Badan Penyehatan perbankan Nasional atau yang sering disingkat BPPN dan memberikan release and discharge $(R \& D)$ kepada beberapa obligator kelas kakap. Keinginan Pemerintah ini dipandang masyarakat sebagai tindakan yang mengarah kepada keuntungan pribadi/ kelompok tertentu dan tidak memperhatikan kepentingan rakyat banyak.

Merosotnya kepercayaan masyarakat terhadap Pemerintah yang berkuasa pada waktu itu menyebabkan tingkat perekonomian nasional semakin melemak dan dampak : kemerosoan tersebut sangat terasa oleh masyarakat pada akhir tahun 2003. Meningkatnya harga-harga kebutuhan pokok, kenaikan harga BBM, tarif dasar listrik (TDL), tarif angkutan umum dan tarif telepon merupakan sejumlah dampak yang timbul akibat merosotnya laju perekonomian nasional. Terhadap kondisi tersebut di atas, muncul sejumlah kritik pedas terhadap Pemerintahan Megawati yang pada intinya menilaí bahwa kinerja pemerintahan Megawati di bidang perekonomian buruk.

\section{Intervensi Publik terhadap Hukum dan Proses Penegakan Hukum}

Masalah yang cukup penting dalam kaitannya dengan upaya pembaharuan hukum di Indonesia adalah adanya campur tangan publik terhadap hukum dan terhadap proses penegakan hukum. Bentuk-bentuk intervensi publik tersebut umumnya dilakukan melalui berbagai berita yang dibuat oleh sejumlah media massa. Salah satu kasus hukum yang menyita banyak perhatian masyarakat adalah kasus korupsi yang didalamnya sarat dengan pelanggaran hak terdakwa maupun hak asasi manusia sebagai warga negara.

Sebagaimana diamanatkan oleh TAP MPR RI Nomor XI/1998 tentang Pemerintahan yang Bersih dan Bebas dari KKN, Pemerintah dan para wakil rakyat yang ada di MPR wajib melaksanakan amanah reformasi, yaitu mencegah dan memberantas KKN sampai ke akar-akarnya. Pemberantasan KKN sampai ke akar-akarnya ini perlu dilakukan mengingat KKN merupakan penyebab utama keterpurukan bangsa dan negara Indonesia.

${ }^{3}$ Amir Syamsuddin, Penegakan Hukum Tahun 2003: Antara Harapan dan Ketidakpastian (Jakarta: Center of Law and Justice Studies, Jurnal Keadilan Vol. 2 No. 6,2002$)$, hlm. 6. 
Untuk melaksanakan amanah yang terkandung dalam TAP MPR RI Nomor XI/ 1998, diberlakukanlah sejumlah peraturan pelaksana, antara lain Undang-undang Nomor 28 Tahun 1999 tentang Penyelenggara Negara yang Bersih dan Bebas dari KKN serta Undang-undang Nomor 31 Tahun 1999 tentang Pemberantasan Tindak Pidana Korupsi (UUTPK). UU No. 28 Tahun 1999 kemudian melahirkan Komisi Pemeriksaan Kekayaan Pejabat Negara (KPKPN), yaitu sebuah komisi yang secara khusus bertugas untuk memeriksa kekayaan para penyelenggara negara. UU No. 31 Tahun 1999 melahirkan Komisi Pemberantasan Korupsi (KPK). Kedua komisi inilah yang diharapkan mampu mengembalikan kerangka kebijakan penegakan hukum yang dilakukan Pemerintah ke arah yang benar.

Namun ditengah upaya keras KPKPN memeriksa harta kekayaan para pejabat negara yang terindikasi KKN, intervensi publik melalui DPR dan Pemerintah terjadi. Dengan persetujuan DPR dan Pemerintah, keluarlah Undang-undang Nomor 31 Tahun 2002 tentang Komisi Pemberantas Tindak Pidana Korupsi yang pada intinya membubarkan KPKPN karena dipandang tidak efektif dan efisien. Pembubaran KPKPN ini disinyalir sebagai tindakan DPR yang ingin menghentkan aktivitas KPKPN yang dipandang telah mengganggu kepentingan anggota DPR.

Intervensi publik terhadap hukum dan penegakannya juga tercermin dalam perierapan kebebasan pers. Pemberitaan pers yang terjadi akhir-akhir ini seringkali tidak sesuai dengan kenyataan yang sesungguhnya, diskriminatif karena hanya memuaskan salah satu pihak saja dan bahkan tidak jarang pers dibayar untuk memuat berita yang kebenarannya sengaja dipelintir demi keselamatan, kenyamanan maupun keuntungan pribadi segelintir orang tertentu. Kondisi ini mejadi lebih buruk manakala banyak tokoh dan pengamat menggunakan berita pers yang tidak seimbang itu untuk memberikan komentar-komentar sumir yang akhirnya membingungkan masyarakat. Sebagai contoh dapat dilihat pada berita mengenai kasus penyelewengan dana non budgeter bulog yang melibatkan sejumlah "orang penting". Banyak berita yang dilansir media massa mengenai kasus penyelewengan dana non budgeter bulog tersebut yang semata-mata untuk memuaskan selera masyarakat.

Selain terhadap kasus penyelewengan dana non budgeter bulog, intervensi publik terhadap hukum dan penegakannya di Indonesia juga tampak pada persoalan hukum yang menyangkut PT BPUI. Terhadap kasus tersebut, semua orang ikut berkomentar, bahkan banyak pejabat negara yang nota bene tidak pernah mengikuti persidangan kasus tersebut berani memberikan komentar yang berlebihan, seperti komentar yang menyatakan bahwa putusan pengadilan terhadap kasus PT BPUI buruk, dagelan (humor), bahkan ada juga yang berkomentar bahwa hakim yang menyidangkan kasus PT BPUI harus diperiksa. ${ }^{4}$

Apabila dibandingkan dengan Amerika Serikat, intervensi terhadap proses pengadilan, baik yang Jillakukan oleh publik, tokoh-tokoh

"Baca: Pusat Kajian Hukum dan Keadilan, Wajah Hukum Indonesia Tahun 2003 (Jakarta: Center of Law and Justice Studies, Jurnal Keadilan Vol. 2 No. 6, 2002), hlm. 3. 
maupun elit politik, tidak dimungkinkan untuk terjadi. Hal ini disebabkan karena adanya penerapan asas speedy trial yang bertujuan untuk melindungi kepentingan hukum terdakwa dari pengaruh-pengaruh non yuridis seperti menghindari meluasnya hal mengadili oleh umum (pre trial publicy), menghindari sikap pejabat yang serba menduga-duga sehingga dapat mempengaruhi hak terdakwa untuk memperoleh peradilan yang fair serta untuk menghindari penundaan yang memberi dampak pada kesanggupan terdakwa untuk membela diri. ${ }^{5}$ Kondisi serupa belum dijumpai dalam sistem hukum di Indonesia.

Dalam kondisi apriori, bahkan traumatik terhadap sistem peradilan di Indonesia, wajarlah jika masyarakat berpandangan miris terhadap setiap putusan pengadilan yang dianggap tidak sesuai dengan keinginan publik. Hal ini akhirnya cenderung menurunkan tingkat kepercayaan publik terhadap hukum. Hukum dan upaya penegakannya dianggap buruk, penuh dengan issues korupsi, kolusi dan nepotisme.

Jika ditelaah lebih jauh, intervensi publik terhadap hukum dan penegakan hukum di Indonesia telah mengakibatkan peradilan menjadi tidak bebas, lebih rumit, memakan biaya dan waktu yang banyak untuk menyelesaikan satu sengketa. Intervensi publik itu juga dapat menurunkan kualitas sumber daya manusia penegak hukum. Aparat yang terprovokasi oleh pemberitaaan umumnya akan bertingkah dan bertindak diluar hati nuraninya, di luar prosedur, bahkan berani mengabaikan hukum demi memuaskan keinginan publik semata.

\section{Harapan akan Adanya Pembaharuan} Hukum

Indonesia melalui Undang-undang Dasar 1945nya telah secara jelas menyatakan ketergantungan hukum kepada kekuasaan sehingga menyebabkan setiap proses hukum tidak akan pernah lepas dari pengaruh politik. Sebagai contoh dapat dilihat pada proses hukum yang terjadi di Kejaksaan Agung dengan proses politik di DPR yang saling berkaitan. Kasus dana non budgeter bulog yang melibatkan beberapa pejabat publik sangat dipengaruhi oleh konstelasi politik di DPR sehingga mempengaruhi proses dan hasil dari proses pengadilannya sendiri (trial by the politics).

Penegakan hukum sebagaimana banyak didengungkan masyarakat, baik lokal maupun internasional akhir-akhir ini bukanlah masalah yang mudah, mengingat persoalan hukum itu sendiri sudah sarat dengan muatan-muatan politik. Sebagai contoh dapat dilihat pada kasus Watergate yang melibatkan Presiden Nixon. Muatan politis yang tekandung dalam hukum itulah yang membuat sulitnya dilakukan peradilan secara fair (fair trial). Akibatnya, tersangka/terdakwa pun sulit untuk mendapatkan keadilan karena publik telah lebih dahulu menghakiminya.

Terhadap keberadaan intervensi publik atas hukum dan penegakannya, banyak timbul pro dan kontra. Pihak yang pro beranggapan bahwa hukum adalah hasil dari interaksi politik dan sosial sehingga dengan demikian instrumentalisasi dan politisasi hukum tidak dapat dipandang buruk mengingat kedua hal

5 Joseph J. Senna dan Larry J. Siegel, Introduction to Criminal Justice (St. Paul, New York, West Publishing, 1979), hlm. 259. 
tersebut menempatkan hukum tidak hanya sebagai dependent variable saja, melainkan juga sebagai independent variable dan ini wajar terjadi di negara-negara yang menganut paham demokratis maupun yang menganut paham otoriter. Bagi pihak yang kontra terhadap intervensi publik terhadap hukum dan penegakannya, hukum dipandang terkontaminasi apabila ada unsur-unsur publik di dalamnya. Unsur-unsur publik yang besar kemungkinannya ditumpangi oleh kekuasaan akan mempolitisi hukum sehingga penerapan hukum bertentangan dengan asas-asas demokratisasi seperti asas legalitas, asas pemerataan, assas equality before the law dan asas kemandirian yudikatif, bahkan penerapan hukum mungkin saja melanggar hak-hak asasi manusia. ${ }^{6}$

Kenyataan tentang banyaknya kelemahan hukum di Indonesia membuat makna reformasi hukum di mata dunia usaha gagal. Perpecahan bangsa yang semakin intens terjadi, munculnya gejolak-gejolak sosial di berbagai daerah yang menyebabkan meningkatnya ekskalasi konflik telah membuat perekonomian nasional tidak stabil. Akibatnya, banyak modal lokal dilarikan ke luar negeri dan banyak investor asing batal menanamkan modalnya di Indonesia, atau bahkan menarik kembali modal yang telah ditanamkannya. Ketidakpastian arah ekonomi dalam negeri ini akhirnya mendorong timbulnya tuntutan akan adanya pembaharuan hukum di indonesia.

Perkembangan dan pembaharuan hukum sangat tergantung kepada keputusan politik para pemimpin bangsa. Perkembangan hukum itu sendiri seharusnya sejalan dengan upaya-upaya pembaharuan di bidang hukum, yaitu yang meliputi:

1. substansi (substance) hukum;

2. struktur (structure) hukum serta

3. budaya (culture) dari hukum yang bersangkutan.

Pakar perbandingan hukum Zitelman dalam salah satu tulisannya ${ }^{7}$ mengemukakan "If one accepts that legal science includes not only the techniques of interpreting the texts, principles, rules and standards of a national system, but also the discovery of models for preventing or resolving social conflicts ...." Berdasarkan pendapat tersebut di atas, dapat disimpulkan bahwa untuk dapat mengatasi konflik sosial, perlu pembaharuan hukum secara menyeluruh terhadap segala aspekaspeknya dan hasil dari pembaharuan hukum itu sendiri hendaknya mencerminkan nilainilai yang hidup (living law) di dalam masyarakat yang bersangkutan. Dengan demikian, maka produk hukum yang dihasilkan akan dapat diterima dan diterapkan di masyarakat.

Hukum yang baik tidak hanya baik dalam segi substansi perundang-undangannya saja, melainkan juga harus baik dalam kultur hukum masyarakat, penegak hukum maupun penguasanya. Kultur hukum yang dimaksud dalam konteks pembicaraan ini adalah kultur hukum yang mencakup opini-opini, kebiasaankebiasaan, cara bertindak maupun cara berpikir dari seseorang dengan segala ha!

${ }^{6}$ Muladi, pendapat yang dikemukakan dalam Seminar Tentang Prospek Pemerintah Tahun 2002 yang diselenggarakan Masyarakat Pemerintah Indonesia (MIPA) di Jakarta pada tanggal 26 Januari 2002.

${ }^{7}$ Dalam:Amir Syamsuddin, Penegakan Hukum Tahun 2003: Antara Harapan dan Ketidakpastian (Jakarta, Center for Law and Justice Studies, Jurnal Keadilan Vol. 2 No. 6, 2002) 3 hlm. 8. 
yang berbau hukum. ${ }^{8}$

Selama ini, yang ditonjolkan oleh reformasi hukum hanyalah rancanganrancangan (substansi) yang menarik mengenai reformasi, berbagai keputusan MPR maupun perundang-undangan. Reformasi yang ditonjolkan itu sendiri, yang akhirnya berakhir dengan retorika belaka. Reformasi ini menjadi kurang bermakna karena ide-ide yang muncul belum direalisasikan. Akibatnya, reformasi hukum seolah-olah hanyalah sampul kosong belaka.

\section{Arah Reformasi Hukum}

Secara umum ada 2 (dua) metode pilihan yang dapat dipakai untuk membaharui kondisi hukum di Indonesia. Metode pertama yang dapat dilakukan adalah revolusi total yang artinya dengan gerak cepat membaharuhi segala sesuatu yang berkaitan dengan pembentukan, pelaksanaan dan penegakan hukum. Metode ini dimulai dengan penemuan konstitusi sebagai induk dari hukum kenegaraan, yang kemudian disusul dengan reformasi kelembagaan, baik ditingkat pusat maupun daerah. Selain metode revolusi total, kondisi hukum dapat diperbaharui dengan menciptakan kondisi kontemporer dan tradisional, untuk kemudian secara gradual mereformasi struktur kekuasaan dan garis kebijaksanaan politik dengan paradigmá baru, sesuai dengan tuntutan masyarakat.

Apabila dikaitkan dengan kondisi pembaharuan hukum yang kini sedang dilaksanakan di Indonesia, pembaharuan hukum melalui penciptaan kondisi kontemporer dan tradisional lebih cocok dibandingkan dengan revolusi total. Selain disebabkan oleh keterbatasan kualitas sumber daya aparat pemerintahan yang bersih dari unsur-unsur $\mathrm{KKN}$, ketidaksiapan masyarakat Indonesia terhadap dampak revolusi total merupakan kendala bagi penerapan metode tersebut.

Pembaharuan hukum melalui penciptaan kondisi kontemporer dan tradisional yang ditempuh Indonesia dimulai melalui urun rembuk politis yang digelar dalam Sidang Istimewa MPR bulan Nopember 1998. Upaya tersebut pada dasarnya dilakukan untuk menegakkan dasar-dasar kebijakan yang baru guna menanggapi tuntutan reformasi dalam ketatanegaraan dan politik. Berkenaan dengan pemilihan Presiden secara langsung bulan Juli 2004, urun rembuk juga dilakukan guna menyusun kelembagaan baru yang selanjutnya bertugas merumuskan public policy yang baru pula, sesuai dengan paradigma kebijakan yang disepakati.

Sejauh mana dan seberapa lama lagi upaya reformasi hukum itu akan berjalan, tergantung pada seberat apa beban reformasi yang bersangkutan. Singkatnya, rekonstruksi sosial politik, sosial ekonomi, sosial budaya dan hankam harus dilakukan secara berkelanjutan, hingga hal itu kembali kepada posisi dan sistem yang wahar, sebagaimana yang dituntut masyarakat, yaitu kembali kepada nilai-nilai dan prinsip-prinsip dasar menurut konstitusi yang berlaku, baik yang tertulis maupun tidak tertulis.

Agar reformasi hukum dapat berhasil, perlu kondisi yang tenang, adanya toleransi antar kontak sosial yang terjadi di masyarakat,

${ }^{8}$ Lihat:Achmad Ali, Keterpunkkan Hukum di Indonesia (Jakarta, Ghalia Indonesia, 2002), hlm 20. 
adanya semangat kekeluargaan dan toleransi dalam menyususn konsep kebijakan yang baru dan merealisaskannya secara teratur, tertib dan terhormat. Untuk itu, nilai-nilai luhur dan kepribadian bangsa sebagai manusia dan warga yang beriman dan bertakwa kepada Tuhan yang maha Esa periu dijunjung tinggi dan diterapkan dalam pemikiran serta tindakan sehari-hari.

Selain pembaharuan moral/aklak, perluasan wawasan perlu juga dilakukan supaya produk hukum yang dihasilkan dari reformasi tersebut dapat berdampak baik bagi sektor perekonomian dan bidang-bidang terkait lainnya serta tdak menimbulkan permasalahan baru di masa mendatang. $\mathrm{Hal}$ ini dapat diwujudkan melalui figur-figur yang mempunyai visi kenegarawanan yang berpandangan ke depan (futuristic view), yang mampu memperhitungkan kepentingan bangsa dan negara untuk kurun waktu yang panjang, jauh ke depan dan tidak sekedar untuk tujuan jangka pendek secara pragmatis.

Figur kenegarawanan lebih diutamakan dalam rangka pelaksanaan reformasi hukum karena seorang politisi belum tentu memiliki kapasitas dan mampu berperan sebagai negarawan. Sebaliknya, seorang negarawan pasti mempunyai kapasitas sebagai politisi, bahkan memiliki nilai tambah lainnya. Figurfigur yang mempunyai nilai plus inilah yang saat ini diperlukan oleh Bangsa Indonesia.

Ada hubungan yang sangat erat antara politik dan hukum dan keduanya ibarat 2 (dua) sisi wajah dari sebuah mata uang logam (two faces of a coin), saling menentukan dan saling mengisi. Kadangkala kebijakan politis harus berperan utama dalam menentukan materi hukum yang sebaiknya berlaku di suatu negara, sesuai dengan pandangan dan pertimbangan politik. Sebaliknya pula, seringkali hukum harus memegang peranan utama dalam mengatur lalu lintas kehidupan politik di dalam masyarakat setempat, baik yang ada dalam suprastruktur maupun infrastruktur politiknya, baik dikalangan partai politik sebagai nucleusnya maupun bagi ormas-ormas politik selaku plasma masyarakat yang bersangkutan.

Dalam reformasi hukum, besar kecilnya peranan hukum maupun politis tergantung pada perkembangan kebutuhan dan tuntutan hidup masyarakat yang bersangkutan, dengan memperhatikan sosio politis dan filosofis yang harus dilayani serta mengacu kepada asas demokrasi dan keadilan sosial yang berlaku di wilayah itu. Pengabaian terhadap aspekaspek sosio politis dan filosofis yang harus dilayani atau kurang peduli terhadap asas demokrasi dan keadilan sosial yang berlaku dapat menyebabkan kontradiksi antara sistem hukum dan aspirasi politik yang sedang dianut sebagai pendapat umum. Kontradiksi inilah yang selanjutnya dapat mengakibatkan gonjang ganjing dibidang perekonomian nasional dan instabilitas di sektor hankamnas. Gonjang ganjing itu baru akan mereda jika kontradiksi itu dikaji ulang, direvisi dan direformasi kembali. Dengan demikian, spanning yang telah terjadi dapat mereda dan kembali pada titik dimana stabilitas dapat dinikmati semua pihak.

\section{Perlunya Manajemen Strategis Demi Keberhasilan Reformasi Hukum}

Mengingat sistem hukum nasional merupakan salah satu sub sistem dalam kehidupan nasional berbangsa dan bernegara dan politik hukum merupakan salah satu súbsistem dari sistem politik nasional, maka 
sewajarnyalah jika kedua sistem tersebut dijaga korelasi dan penerapannya secara baik. Setiap pemikiran, baik mengenai sistem hukum maupun politik hukum harus berpedoman pada pandangan bahwa keduanya merupakan bagian yang integral dan kontekstual dalam sistem nasional bangsa dan negara yang bersangkutan. Pengaruh timbal balik yang ditimbulkan oleh korlasi kedua subsistem itu perlu juga diperhitungkan secara cermat, termasuk korelasinya dengan sub-sub sistem lainnya dalam konteks manajemen kehidupan nasional.

Belajar dari pengalaman masa lampau dimana kebijakan hukum sedikit banyak pasti dipengaruhi oleh kepentingan-kepentingan politis tertentu dan penerapan kebijakan hukum itu sendiri besar maknanya bagi perubahan struktur perekonomian nasional, maka sewajarnyalah jika dalam setiap tindakan yang mengarah kepada reformasi hukum dilakukan manajemen strategis.

Banyak pakar membuat definisi tentang manajemen, antara lain George R. Terry ${ }^{9}$ yang mendefinisikan manajemen sebagai "distinict process consisting of planinning, organizing, actuating and controlling performed to determine and accomplish stated objectives by the use of human being and other resources." Dari pendapatnya iłu, Terry menekankan bahwa manajemen adalah suatu proses khusus. Proses khusus itu sendiri terdiri dari 4 (empat) aktivitas, yaitu perencanaan, pengorganisasian, pelaksanaan dan pengawasan yang dilakukan untuk menentukan serta mencapai sasaran yang telah ditentukan melalui pemanfaatan sumber daya manusia dan lainnya.

Menurut John D. Millet, ${ }^{10}$ manajemen diartikan sebagai berikut: " management is the process directing and facilitating the work of people organized in formal group to achieve a desired end." Berdasarkan pengertian di atas dapat dikatakan bahwa Millet memandang manajemen dari sudut pandang organisasi yang berkecimpung dalam suatu pekerjaan. Pengertian manajemen menurut Millet adalah suatu proses kepemimpinan dan pemberian arah terhadap pekerjaan yang terorganisasi dalam kelompok formal untuk mencapai tujuan yang dikehendaki.

Berdasarkan beberapa pengertian tentang manajemen yang diberikan sejumlah pakar seperti tersebut di atas, dapat ditarik suatu gambaran umum tentang manajemen; yaitu suatu rangkaian proses yang mengarah kepada perwujudan suatu tujuan tertentu. Dalam proses tersebut, terkandung sejumlah unsur-unsur yang masing-masing unsur tersebut sub-sub bagian dari manajemen itu sendiri. Unsur-unsur yang terkandung di dalam manajemen dapat sama dengan fungsi manajemen atau tidak sama sekali. Dalam kaitannya dengan organisasi swasta maupun pemerintahan, unsur-unsur yang terkandung. di dalam proses manajemen antara lain berupa:

1. Komunikasi, yaitu keberadaan tata hubungan, baik yang timbal balik maupun yang searah, antara atasan dan bawahan;

2. Tata usaha, yaitu keberadaan pengaturan dan pengurusan surat-surat, meliputi pengiriman, penerimaan maupun

- George R. Terry, Principles of Management (USA, Richard D. Irwin Inc., 1972), hlm. 4.

10 John, D. Millet, Management in the Public Services (New York, Mc Graw Hill Book Co. Inc., 1954), hlm.1. 
pengarsipan;

3. Perbekalan, yaitu keberadaan pengaturan dan pengurusan barang-barang yang meliputi pemesanan, pengadaan, penyimpanan, penghapusan, pengiriman dan pemakaian;

4. Keuangan, yaitu keberadaan dan pengaturan pengurusan uang, meliputi pendanaan, pembiayaan, pembelanjaan, pemasukan maupun hutang piutang lainnya;

5. Kepegawaian, yaitu keberadaan pengaturan dan pengurusan personalia yang meliputi pemindahan, pemberhentian, pengangkatan maupun pemberian hadiah dan sanksi serta

6. Kepemimpinan, yaitu keberadaan pengaturan dan pengurusan seluruh seluruh pengarahan dan pengomandoan organisasi.

Agar suatu manajemen dapat dilakukan dengan tertib, efektif dan efisien, dibuatlah pembagian dan pengelompokan atau klasifikasi pekerjaan. Pertimbangan pembuatan klasifikasi tersebut sangat relatif, tergantung pada jenis dan tipe organisasi, kemampuan sumber daya organisasi dan sasaran yang hendak dicapai. Karena itu, beberapa ahli manajemen mengklasifikasikan fungsi manajemen tersebut berdasarkan sudut pandang yang bermacam-macam, namun dalam satu prinsip manajemen yang sama, yaitu untuk mencapai ketertiban, keefektifan dan efisiensi. Adapun fungsi-fungsi manajemen tersebut antara lain:

1. Menurut Dalton E. Mc Farlan: ${ }^{11}$ planning (perencanaan), . organizing (pengorganisasian), dan controlling (pengawasan), atau yang disingkat dengan akronim POCO;

2. Menurut Newman:12 - planning (perencanaan), . organizing (pengorganisasian), assembling resources (pengumpulan sumber daya), supervising (pengendalian kerja) dan controlling (pengawasan), atau yang disingkat dengan akronim POASCO;

3. Menurut Harold Koontz dan Cyrill O'Donnel ${ }^{13}$ : planning (perencanaan), organizing (pengorganisasian), staffing (penyusunan pegawai), directing (pengarahan kerja) dan controlling (pengawasan) atau yang disingkat dengan akronim POSDICO;

4. Menurut Luther M. Gullick ${ }^{14}$ : planning (perencanaan), organizing (pengorganisasian), staffing (penyusunan pegawai), directing (pengarahan), coordinating (pengkoordinasian), reporting (pelaporan) dan budgeting (anggaran) atau yang disingkat dengan akronim POSDCORB;

"Dalton E. Mc. Farlan, Management Principles and Practices(New York, MacMillan Co., 1959), hlm. 42.

${ }^{12}$ William H. Newman, Administrative Action: The Technique of Organization and Management (New York, Prentice Hall Inc., 1963), hlm. 4.

${ }^{13}$ Harold Koontz and O'Donnel, Principles of Management, An Analysis of Management Function (New York, Mc Graw Hill Book Company, 1968), hlm. 70.

${ }^{14}$ Luther M. Gullick, The Theory of Administration (New York, Institute of Public Administration, 1937), hlm. 13. 
5. Menurut George R. Terry: ${ }^{15}$ planning (perencanaan), (pengorganisasian), (penggerakan) dan (pengawasan);

6. Menurut Gibson et.al. ${ }^{16}$ planning (perencanaan), organizing (pengorganisasian) dan controlling (pengawasan), atau yang disingkat dengan akronim POC.

Berdasarkan sejumlah pendapat para ahli tersebut di atas, dapat diambil inti sari bahwa fungsi manajemen adalah sebagai berikut:

1. Perencanaan (planning), yaitu tentang bagaimana merencanakan tujuan bersama organisasi;

2. Pengorganisasian (organizing), yaitu tentang bagaimana mendirikan wadah. struktur resmi;

3. Penyusunan staf (departemensi (staffing), yaitu tentang bagaimana seluruh personal bawahan difungsikan;

4. Penggerakan (actuating), yaitu tentang bagaimana menyelenggarakan pekerjaan organisasi sesuai dengan rencana secara efisien dan efektif dan

5. Pengendalian/pengawasan (controlling), yaitu tentang bagaimana mengawasi, mengantisipasi dan mendeteksi kemungkinan-kemungkinan penyimpangan pelaksanaan organisasi dari apa yang telah dirumuskan semula.

Sedangkan fungsi manajemen yang lainnya dapat dikatakan sebagai pelengkap, yaitu fungsi sebagai:
1. Directing, yaitu bagaimana tugas rutin diputuskan, dipimpin dan diatur;

2. Coordinating, yaitu bagaimana seluruh kepentingan dan tujuan organisasi disatukan dan diharmoniskan dengan sinkronisasi waktu serta tempat;

3. Reporting, yaitu bagaimana menginformasikan pertanggungjawaban;

4. Budgeting, yaitu bagaimana merencanakan keuangan, pembiayaan, perhitungan uang keluar masuk serta pengawasan yang dilaksanakan;

5. Commanding, yaitu bagaimana memberikan perintah, diatur, diurus, dilayani, dibujuk dan diarahkan agar tujuan organisasi tercapai secara efisien dan efektif;

6. Motivating, yaitu bagaimana mendorong bawahan dengan segala cara, baik dengan cara kharismatis diri, dengan keputusan mengikat, dengan pemberian maupun dengan paksaan agar sadar, terbujuk serta terpengaruh melaksanakan tugas organisasi;

7. Leading, yaitu bagaimana kemampuan mempengaruhi bawahan agar pikirannya tertuju kepada apa yang diinginkan pimpinan dan

8. Facillitating, yaitu bagaimana cara memudahkan pekerjaan bawahan sehingga sasaran organisasi semakin jelas.

Selain sebagai ilmu, manajemen juga dapat dipandang sebagai seni. Manajemen sebagai seni akan lebih tampak pada saat

${ }^{15}$ George R. Terry, Principles of Management (New York, Richard D. Irwin. Inc., 1961), hlm. 121.

${ }^{16}$ James L. John M. Gibson, et. al., Organizations (New York, Business Publications Inc., 1982), hlm. 35. 
seorang manager mampu menyelenggarakan, menata dan mengurus organisasinya tanpa keterpaksaan dari bawahannya. Sebagai contoh, lihatlah bagaimana kemahiran dan kiat managerial pemerintahan dalam upayanya menyatukan suatu negara.

Suatu manajemen merupakan masalah yang besar jika setelah faktor dan sumber daya yang paling sulit untuk dikendalikan dan didayagunakan masuk ke dalam manusia. Apabila faktor dan sumber daya yang paling sulit itu telah masuk dan berinteraksi dalam diri individu, maka akan sulit bagi individu tersebut untuk melakukan interaksi dan tawarmenawar dengan individu-individu lainnya. Hal ini akhimya akan menghambat keberhasilan manajemen. Apabila individu itu adalah pemegang kekuasaan tertinggi di jajaran pemerintahan suatu negara, maka kebijakan yang dihasilkan oleh negara cenderung terfokus pada kepentingan the highest order.

\section{Simpulan}

Kenyataan tentang banyaknya kelemahan hukum di Indonesia membuat makna reformasi hukum di mata dunia usaha gagal. Perpecahan bangsa yang semakin intens terjadi, munculnya gejolak-gejolak sosial di berbagai daerah yang menyebabkan meningkatnya ekskalasi konflik telah membuat perekonomian nasional tidak stabil. Akibatnya, banyak modal lokal dilarikan ke luar negeri dan banyak investor asing batal menanamkan modalnya di Indonesia, atau bahkan menarik kembali modal yang telah ditanamkannya. Ketidakpastian arah ekonomi dalam negeri ini akhirnya mendorong timbulnya tuntutan akan adanya pembaharuan hukum di Indonesia.
Perkembangan dan pembaharuan hukum sangat tergantung kepada keputusan politik para pemimpin bangsa. Perkembangan hukum itu sendiri seharusnya sejalan dengan upaya-upaya pembaharuan dibidang hukum, yaitu yang meliputi substansi (substance) hukum, struktur (structure) hukum serta budaya (culture) dari hukum yang bersangkutan. Reformasi hukum sedikit banyak memuat unsur-unsur politis. Suatu produk hukum yang dihasilkan dari reformasi dapat mengubah arah dan warna perekonomian nasional. Kesalahan dan/atau kelalaian sekecil apapun yang dilakukan dalam proses reformasi akan membawa dampak pada pertumbuhan ekonomi nasional.

Likuidasi bank secara besar-besaran di tahun 1990-an merupakan salah satu penerapan kebijakan moneter oleh pemerintah di sektor ekonomi yang akhimya menimbulkan gejolak ekonomi dan instabilitas keamanan di Indonesia. Bercermin pada pengalaman di masa lampau itulah, maka reformasi hukum yang kini sedang gencargencarnya didengungkan hendaknya dilakukan dengan manajemen statejik tertentu, sesuai dengan latar belakang ekonomi, politik, sosial, budaya dan filosofi yang berlaku di masyarakat yang bersangkutan.

\section{Daftar Pustaka}

Ali, Achmad. Keterpurukan Hukum di Indonesia. Jakarta: Ghalia Indonesia, 2002.

Farlan, Dalton E. Mc. Management Principles and Practices. New York! Mac Millan Co., 1959. 
Gibson, James L. John M., et. al., Organizations. New York: Bussiness Publications Inc., 1982.

Gullick, Luther M. The Theory of Administration. New York: Institute of Public Administration, 1937.

Hager, L. Michael. Peranan Hukum di Masa Transisi Demokrasi Negara Berkembang. Jakarta: Center of Law and Justice Studies, Jurnal Keadilan Vol. 1 No. 2, Juni 2002.

Koontz, Harold and O'Donnel. Principles of Management, An Analysis of Management Function. New York: Mc Graw Hill Book Company, 1968.

Lubis, Solly. Politik dan Hukum di Era Reformasi. Bandung: Mandar Maju, 2000.

Millet, John, D. Management in the Public Services. New York: Mc Graw Hill Book Co. Inc., 1954.
Muladi. Seminar Tentang Prospek Pemerintah Tahun 2002 yang diselenggarakan oleh Masyarakat Pemerintah Indonesia (MIPA) di Jakarta pada tanggal 26 Januari 2002.

Pusat Kajian Hukum dan Keadilan. Wajah Hukum Indonesia Tahun 2003. Jakarta: Center of Law and Justice Studies, Jumal Keadilan Vol. 2 №. 6, 2002.

Syamsuddin, Amir. Penegakan Hukum Tahun 2003: Antara Harapan dan Ketidakpastian. Jakarta: Center of Law and Justice Studies, Jurnal Keadilan Vol. 2 No. 6, 2002.

Senna, Joseph J. dan Siegel, Larry J. Introduction to Criminal Justice. St. Paul, New York: West Publishing, 1979.

Terry, George R. Principles of Management. New York: Richard D. IIwin. Inc., 1961. Principles of Management. New York: Richard D. Irwin Inc., 1972.

Newman, William H. Administrative Action: The Technique of Organization and Management. New York: Prentice Hall Inc., 1963. 